\title{
CREATING SUPPORTIVE LEARNING ENVIRONMENTS: EXPERIENCES OF LESBIAN AND GAY-PARENTED FAMILIES IN SOUTH AFRICAN SCHOOLS
}

\author{
Diana Breshears \\ University of Pretoria \\ University of the Free State \\ Email: diana.breshears@gmail.com
}

\section{Carien Lubbe-De Beer}

University of Pretoria

Email: Carien.Lubbe@up.ac.za

\section{ABSTRACT}

Through in-depth interviews with 21 parents and 12 children in lesbian/gayparented families, we explored the experiences of this unique family form in South African schools. Specifically, families reflected on their positive and negative experiences in the children's education and used these reflections to offer advice to teachers and administrators wishing better to support lesbian/ gay-parented families. The results of our study offer an understanding of the challenges and needs of this diverse family in the school system, as well as a starting point for administrators and teachers wanting to create inclusive environments for all family types.

Keywords: Inclusive education; lesbian/gay-parented families; South Africa; supportive schools

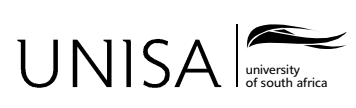

Education as Change

Volume 20 | Number 2 | 2016 | pp. 86-105

www.educationaschange.co.za
DOI: http://dx.doi.org/10.17159/1947-9417/2016/606 Print ISSN 1682-3206 | Online 1947-9417

(c) 2016 The Author(s) 


\section{INTRODUCTION}

With the legalisation of same-sex marriage and adoption in South Africa, and an increase in the availability and acceptance of reproductive technology, there is a mirrored growth in the presence of lesbian/gay-parented families in this developing nation (Lubbe 2007a). The progressive laws, however, are not reflected in cultural attitudes. In a survey conducted between 2003 and 2007, South Africans were asked whether they believe it wrong or not wrong for same-sex adults to engage in sexual relations (Roberts \& Reddy 2008). In all five years, more than $80 \%$ of participants reported that same-sex sexual relations are wrong. More recently, a survey of world values showed that $61 \%$ of South Africans believe that homosexuality should not be accepted in society (Pew Research Center 2013). As a result of current social attitudes, lesbian and gay individuals and their families are required to navigate daily life within a homonegative society (Knoesen 2004; Lubbe 2007a; Singh 1995). Though there is a steady increase in research exploring the lived experiences of lesbian and gay individuals in this social context, very few studies have explored the experiences of lesbians and gay men as parents, or of their children (Lubbe 2007a; 2007b). The formative impact of school experiences, specifically, is potentially very powerful, as school is the first context in which many children are confronted with messages that contradict their understanding of their family (Fedewa \& Clark 2009). The current study begins to shed light on this phenomenon by exploring the positive and negative experiences of lesbian/gay parents and their children in South African schools, as well as the advice these families have for educators and administrators wishing to improve school climates for these families.

Realising the importance of supportive school environments, international researchers have begun to explore the experiences of lesbian/gay-parented families in schools (Byard, Kosciw \& Bartkiewicz 2013). Lesbian/gay-parented families remain underrepresented, largely ignored, and even presented as deviant in education (Byard et al. 2013; Casper, Schultz \& Wickens 1992). Further, children often experience rejection, bullying, or discrimination from their peers (Baptiste $\mathrm{Jr}$ 1987; Breshears 2011; Butler, Alpaslan, Strümpher \& Astbury 2003; Gartrell, Deck, Rodas, Peyser \& Banks 2005; Lewis 1980). In perhaps the largest study of school experiences in the United States, including surveys from 588 lesbian and gay parents and 154 children, Kosciw and Diaz (2008) found that many children reported being mistreated at school for having a lesbian or gay parent, with $40 \%$ reporting verbal harassment because of their families. Indeed, school years may be the most difficult for children with same-sex parents (Goldberg 2010; Ray \& Gregory 2001). Parents also report feelings of discomfort and/or rejection by school employees (Kosciw \& Diaz 2008; Lindsay, Perlesz, Brown, Mcnair, De Vaus \& Pitts 2006).

In South Africa, research exploring same-sex parented families' educational experiences is extremely limited. The research that has been conducted shows classroom climates to be extremely homophobic and even antagonistic toward 
homosexuality (Bhana 2012; Butler et al. 2003; Francis \& Msibi 2011; Msibi 2012). Though most of this research focuses on the experiences of LGBT learners, it is likely that children of lesbian/gay parents also internalise these discourses as messages about their family identity. To date, only one study explored the experiences of children with lesbian parents in South African classrooms (Lubbe 2007b). In her interviews with eight children with lesbian parents, Lubbe found that school experiences largely relied on whether or not the school environment was supportive or non-supportive of the children's family type. That is, children reported positive experiences following disclosure of their family identity when schools were welcoming and accepting of lesbian/gay parenting, and reported negative experiences within non-supportive schools. Children also reported incidents of teachers sharing religious beliefs against homosexuality within the classroom context. This finding is not surprising in light of research showing that much of the homophobia in South African education is created or perpetuated by teachers (Bhana 2012; Francis 2012; Msibi 2012).

Extant research demonstrates the necessity for schools to create supportive environments for children with lesbian/gay parents, particularly because of the negative effects that non-supportive school climates can have on the well-being of these children (Bos, Gartrell, Peyser \& Van Balen 2008). In their study of 79 children of lesbian parents, Gartrell et al. (2005) found that when children are confronted with their peers' disapproval of their mothers' sexual orientation, they lose self-confidence and exhibit more behavioural problems. Similarly, in their study of 63 children from lesbian-parented families, Bos and van Balen (2008) found that higher levels of stigmatisation were associated with more hyperactivity for boys and lower self-esteem for girls. In addition to the psychological well-being of children of lesbian/gay parents, supportive school environments are also thought to improve academic experiences, as parents are more inclined to be involved in their children's education when they experience acceptance and support from school personnel (Kosciw \& Diaz 2008; Lindsay et al. 2006). As Byard, Kosciw, and Bartkiewicz summarised,

Ultimately, improvements in school climate that reduce homophobia and transphobia can contribute to greater individual well-being, improved academic achievement, and greater educational attainment among the students most affected by these forms of bias and violence. $(2013,281-282)$

In the current study, we explored ways in which schools can create supportive environments for lesbian/gay-parented families by positing the following research questions:

RQ1: What are the positive and negative experiences of lesbian/gay parents and their children in South African schools?

RQ2: What advice do parents and children have for schools to create a more supportive environment for lesbian/gay-parented families? 


\section{METHODS}

Once ethical clearance was secured through the university's Ethics Board, participants were obtained through a combination of convenience and snowball sampling. Recruitment scripts were posted on public Facebook groups aimed at same-sex parenting and LGBT Pride groups in South Africa. After participating in the study, participants were asked to forward the recruitment script to others who might be willing to take part in the study. The participants in the study included 21 lesbian/ gay parents (including five couples) and 12 children with lesbian/gay parents living in Gauteng $(n=20)$, Western Cape $(n=10)$, Eastern Cape $(n=2)$, and Free State $(n=1)$ provinces. The 21 parents comprised 17 lesbian mothers and four gay fathers, ages 25-56, with a mean age of 40.8 years. Despite previous successes of diverse sampling through recruitment in social media groups (Crouch, Waters, Mcnair, Power, Davis \& Van Mourik 2014), recruitment in the present study resulted in a fairly homogenous sample. All but one parent identified as white, with one mother identifying as Cape Coloured. This lack of diversity, often resulting from convenience sampling of difficult to reach populations (Berkowitz 2009), has important implications for our findings, which will be discussed further. Children in the study comprised five male and seven female participants, ages 12-23, with a mean age of 16 years. All but two children identified as white (one child identified as Cape Coloured and one identified as black) and all but one child was conceived in previous heterosexual relationships and subsequently had a parent come out as lesbian/gay. One child was adopted by a lesbian couple. Of the children represented/participating in the interviews, 11 attended private schools, seven attended government schools, and five attended governing body-funded schools (formerly known as 'Model C' schools).

Data were collected through semi-structured, open-ended interviews, lasting 20-140 minutes, with a mean of 61 minutes. Most interviews took place in the participants' homes, but three families chose to be interviewed in a public setting (e.g., coffee shop) for comfort or scheduling convenience. Children were given the option to be interviewed with or without their parent(s) present. During the interviews, participants were asked to discuss their experiences in South African schools as lesbian/gay-parented families and to provide advice to educators and administrators wishing to create supportive learning environments for families like theirs. We continued to collect interview data to the point of theoretical saturation, which occurs when thematic categories are fully developed and further data do not add to conceptualisation of findings (Corbin \& Strauss 2008). Interview transcripts were analysed with qualitative data analysis software, using the following modified version of Smith's (1995) five-step guide to thematic analysis (i.e., performing electronic notations in place of handwritten notations on hardcopies of transcripts):

1. Transcripts were read completely for data familiarisation. 
2. Transcripts were reread, with the researchers making notations of anything that appeared interesting or significant and beginning a list of emerging themes (i.e., open coding).

3. Emerging themes were analysed for connections and collapsed into categories (i.e., axial coding).

4. A master list of categories and themes were produced for each research question.

5. Identifier instances (i.e., quotations) were added to the master list of themes.

To ensure the validity of our findings, a summary of the findings was sent to the participants for member checking (Strauss \& Corbin 1998). This process allows for participants to provide feedback to researchers, indicating whether or not the findings ring true and to provide any additional information they deem appropriate.

\section{RESULTS}

As most participants in the current study are of middle to upper-middle socioeconomic status, it is important to note that their experiences are not representative of the general population. The majority of the families send (or have sent) their children to private or semi-private schools, which are not the school types that the majority of South African children attend. Absent from this study are the experiences of samesex parented families in low-resourced, government schools. It can be argued that due to the parents' awareness of heteronormativity and the associated risk, the parents took great care in deciding which schools their children attend. The latter is however a luxury that families from low income situations cannot afford. The discussion of the following findings are therefore framed within the context of parents from higher income groups that had a choice in where they live and the schools that the children subsequently attend.

\section{CHALLENGES IN THE SCHOOL ENVIRONMENT}

Our first goal for RQ1 was to understand the challenges that lesbian/gay-parented families face in South African schools. The challenges that participants reported were both actual situations that occurred as well as anticipated challenges that participants think they may face in the future. Four specific challenges emerged from the data.

\section{(Fear of) teasing}

When parents in our study discussed concerns that they had for their children as a result of having a lesbian/gay parent, they overwhelmingly reported fear that their children will be victimised in school. One father shared, 
The fear is not for me but the fear is what kind of stuff is going to be directed at my children in terms of bullying and teasing and that kind of thing. So, I can deal with it, I think you can deal with it. I'm not sure that my children can or need to deal with it. So that's where my issues lie.

Similarly, one mother reported,

Well obviously, especially for [my son], because he's still at school...I was scared that he would be victimised by his friends.

As can be seen from above, when parents discussed coming out as lesbian/gay, many downplayed concerns they had for themselves and focused instead on how their identity would affect their children.

These fears of potential teasing were sometimes realised. Though most children reported acceptance by their friends and peers, some experienced teasing as a result of having lesbian/gay parents. One 13-year-old girl shared her thoughts about her mother's coming out,

So I was more curious to know what my friends would think at school and if they would tease me, which they did start to do last year before I moved to a new school this year. So they started saying if my mom is lesbian, then I should be lesbian. Then I said to them 'no' and I got into this big fight with them.

Another instance of teasing emerged from the following discussion with a mother and daughter (age 12).

Mother: When I came out - especially [my daughter], they used to bully her about having two moms that are gay. She was bullied a bit.

Interviewer: How did you respond when people bullied you?

Mother: She used to cry.

Daughter: Yeah, I never actually told any teachers because they'd never actually do anything.

These instances demonstrate that children are sometimes subjected to teasing, with the consequence of conflict in peer relationships and feelings of sadness. More pertinently, the latter example reflects how children do not always perceive teachers as a source of support or protection. Though children experienced teasing and bullying, these instances were often short-lived and the children reported high levels of resilience.

\section{(Fear of) rejection or judgment}

Another concern reported by both parents and children about the school context was judgment the children may face as a result of their familial identity. One adult child reflected on the fear she had in grade school, 
In Grade 5 or 6 we had Life Orientation as a subject, when all of that kind of thing is discussed, and at that stage I was concerned-I think I wasn't ashamed of it, I just didn't know what other people's reactions would be and also I didn't want it to come up in class and for it to be awkward.

As with teasing, these concerns were sometimes realised. One mother shared the experiences of her daughters,

She was judged because of me. She was deprived of some sporting positions because of me...And then came high school and there was this Christian group that came after school and they had this concert and told everyone that gay people are going to hell and there are my two kids knocked to the ground because now Mommy is going to hell.

For this parent, her sexual orientation and her child's opportunities in the school are directly linked. Furthermore, this parent acknowledged the role of religious discourse in creating a homonegative school environment. These experiences highlight the importance of family diversity education in the classroom, teaching children to accept difference, as well as the need to shield children from the prejudices of school personnel. Overall, participants were largely concerned about reactions by the children's peers at the discovery of their family identity, but also reported concerns about reactions from teachers and other children's parents.

\section{Family-specific school assignments}

When discussing specific challenges that arise in the school context, participants also discussed school assignments that highlight their family identity. These assignments included making cards for Mother's Day or Father's Day, Family Tree assignments, and 'My Family' drawings or reports. For some, these assignments required children to provide a public explanation of their family form, even if they were not yet ready to come out as having lesbian/gay parents. One 15-year-old girl shared,

Participant: There was this whole thing about your family. Like you had to do a whole oral about your family and everything so obviously I had to stand up there and be like-They knew I had a white Mom and stuff because of the dropping off, but it was more like in their face when I had to do the my family thing.

Interviewer: Were you glad when you did that presentation, or did you wish you didn't have to?

Participant: I don't know. I think at the time then I was like, 'Why did I do that? I should have pretended to forget it at home'. But now I just don't see them anymore, it's over, it's passed.

Though it is no longer an issue for this child, at the time this family assignment put her in a challenging situation where she had to decide whether or not to lie about her family identity. These family assignments sometimes resulted in children hiding their family, as was reported by the following couple in a stepfamily, 
Stepmother: I do think, though, that when the kids get specifically family assignmentsMother: That is tricky.

Stepmother: Either it will be just their mom and them, or just them. I don't think they include me. So, I think they approach how they do that activity differently. I don't think they go and portray the family as it really looks.

Mother: I remember that was quite hurtful, and I do remember one of the kids was required to draw a picture of the family, and they drew the industry standard.

Interviewer: The father, mother...?

Mother: Yeah. It was so upsetting. But I thought, 'you know? It's not my stuff'. If that's how they want to see the world...

Though seemingly innocuous, family assignments can place children in difficult situations in which they are either forced to come out in a public setting or to hide family members as a form of self-preservation.

\section{Backlash from other parents}

The final issue parents reported in the school context was the schools' fear of parental backlash if they were to incorporate non-heteronormative curricula. When discussing the level of support in South African schools, many parents attributed the lack of progress to administrators' and teachers' fear of the response they would receive from heterosexual parents if they were openly to discuss and support homosexuality and families in the classroom. One father summarised the issue by stating,

I think schools are very scared to take a stand on those issues because of the backlash of the parents. I think there will be a really big backlash from parents if they really take a stand for diversity... They will just go, 'That's fine. You should accept anybody. People of colour, people with disabilities, gay people'. It will be in that context. But I don't think they will specifically teach children about being gay. I don't think they do that. So there's a fine balance that the school has to keep in order not to have a backlash from the parents as far as that is concerned. Parents are very influential in our school system in South Africa, because of the structure - they have governing bodies that are run by parents. Schools are essentially run by parents.

Though schools may teach that students should not discriminate against specific groups, including the lesbian/gay community, issues around lesbian/gay-parented families are often brushed over, and schools stop short of providing positive representations of these families in the classroom. Participants attributed this omission to the schools' aversion to backlash from parents in traditional family forms. 


\section{SUPPORTIVE EXPERIENCES IN SCHOOLS}

Our second goal for RQ1 was to understand the positive experiences of lesbian/gayparented families in South African schools. The parents that reported positive school experiences often actively chose schools that would support their family type and other forms of diversity. Two specific types of positive experiences emerged from the data.

\section{Bullying policies and interventions}

Some parents and children in the study praised their schools when they demonstrated efforts to end gender- and sexuality-related bullying. One mother and daughter shared,

Daughter: The teachers say, 'Stop this. Stop bullying in that way', and if it gets too serious for them, they can go to the principal and they speak with the parents. [Bullying] is a very serious thing in the school.

Mother: The governing body will have a hearing, with all other things. Three warnings with bullying is immediate suspension.

Similarly, a father discussed his school's approach to bullying,

Bullying is such a major problem, and we have channels to deal with it, and we do deal with it...When stuff happens, you deal with it as parents, it goes to the school counsellor if it needs to be. So there's always a solution.

Parents perceived that the schools' attempts to end bullying were positive steps toward creating supportive environments for their children and children who identify as (or are perceived to be) queer. However, most families reported a lack of policy that includes lesbian/gay-specific bullying in their schools and discussed many instances of witnessing lesbian/gay students being bullied.

\section{Full acceptance/inclusion}

Some parents reported that their schools actively supported their families and fully included both parents in school activities. The parents who experienced full acceptance actively chose the school based on the schools' reputation for including diversity in the curriculum. One mother shared their experience while searching for a supportive school,

One of the mothers was very much involved in the school on the PTA and all of those things, and she was very open to us about staff members who are gay and that it's a great school and they'll accept you, and they'll be wonderful. Because I was a bit sceptical around it as a Catholic school. But again, based on the feedback that we had from her, it was just so positive. 
The expectation of a supportive environment was confirmed when her partner shared, 'There is that degree of curiosity, but I also think that we're viewed as a positive family. We're very involved in school and they're always very appreciative of that fact, and very complimentary of us as a family'. Another father shared the full acceptance that he and his family experienced at their sons' school,

I think it's been easy because the focus has never been on us as parents. The focus is constantly on our children and what are they getting, what are their needs, how are they coping?...And we are heard, we are on the diversity working group, and we express our issues. We have taken 'And Tango Makes Three' and all of these books and the principal has taken books too and read them to the Grade $1 \mathrm{~s}$ and the Grade $2 \mathrm{~s}$. So, there is an openness and a willingness to embrace difference.

Parents who perceived their families as being fully accepted and included in the school environment overwhelmingly reported positive experiences for their children. It appears that a supportive environment is characterised by acceptance of sexual diversity in general (including teachers, children and parents who self-identify as lesbian/gay). Furthermore, the active involvement of parents facilitates positive relationships. A child-centred school climate, creative initiatives such as diversity groups, and openness to incorporate suggestions from parents into the classroom enhances support to lesbian/gay-parented families. Unfortunately, the majority of participants do not experience this level of support from their children's schools.

\section{ADVICE TO SCHOOLS}

Reflecting on their positive and challenging experiences in South African schools, families were asked to provide advice for schools wishing to create a supportive environment for children with lesbian/gay parents. Four suggestions emerged from their responses.

\section{Heightened awareness of lesbian/gay-parented families}

Participants overwhelmingly believe that schools need to create awareness and visibility of same-sex parented families through the education of teachers, students, and parents about diverse family forms. One mother suggested,

I think [my advice] would be to explain that there are different families across the board. And I think society has so many configurations of families that it's easier to explain. In South Africa, you have a lot of families where grannies and gogos raise the children, and a lot of single mother families in this country. For me it would be around it's just another permutation of the family structure.

Before children and other parents can be educated about diverse families, however, parents stressed that educators and administrators first need to be educated. One mother shared her frustration with the heteronormativity of school administrators, 
[The school] is very patriarchal...It's amazing that they have put so many other educational things in place that they just kind of avoid the whole gay issue. It's just not something that is ever discussed. Every bit of communication I get from them is about family and they're talking about heterosexual families...everything is the assumption that you are a heterosexual couple.

In addition to administrators, parents also discussed the need for teachers to be trained about diverse families before they can effectively teach children to support and embrace diversity. One mother shared,

You have to educate your teachers first...Teach them. Send them back; they must go do a course about it. They must learn. And if they are still homophobic, find someone else that is willing. Get a parent in that is willing to talk about it. Get someone in who is willing to handle the situation.

It is important to note that, while families expressed a desire for heightened awareness of lesbian/gay-parented families, many people expressed that this awareness should not include spotlighting specific students in the class with lesbian/gay parents. That is, family diversity should be discussed in a general sense, rather than discussing the families of specific students in a public manner. One couple explained,

Mother 1: I think the key thing is not to make the child feel any different to any of the other children, because they don't want to feel any different. They want to feel exactly the same as their little friend.

Mother 2: You don't discuss that you have a mommy and daddy, so why do you need to discuss that you have two mothers? So for me, it would be treat it normally, downplay it, but be open and frank when questions do come of it.

An adult child echoed this suggestion to educate without spotlighting specific students,

I think the biggest thing is to not ignore it, but at the same time not make a spectacle of it. You don't want them to stand out and be different and 'Ok, here we have a gay family. We're going to chat about them today and how everyone feels about them' because that can just isolate a person further. While it needs to be acknowledged in case of negativity, I think it should just be a non-issue.

Overall, these participants believe that lesbian/gay-parented families should be acknowledged and discussed in the classroom, but without bringing attention to specific students who may not be comfortable discussing their family identity in a public space.

Though many participants desire more education and awareness of lesbian/ gay-parented families, it is important to acknowledge that some participants believe sexuality should not be addressed in schools. One mother explained, 
For me personally, the focus should not be on the sexual orientation, the focus should be on what it is we need to do here...At the end of the day, being at an educational institution is about getting your grade and writing your exam, passing your exam, and moving onto the next level... When it starts impacting whatever we do there, obviously if it's a negative effect, then we need to look at that.

Parents in this category are more private about their sexual identity in general and feel that it should not have a place in their children's education.

\section{Family-specific activities in curriculum}

Another suggestion families had for schools was to create sensitivity around family activities. Many parents and children raised the issue of Father's Day and Mother's Day activities, expressing a need for teachers to create alternative activities for children who may not have a mother or father, but instead have two mothers or two fathers. One mother and daughter explained,

Mother: I think for me things like around Mother's Day and Father's Day, just an understanding in the lower grades that they need to make Father's Day cards... Just have the understanding that it's insensitive for the kid who doesn't have a dad to have to make a Father's Day card or even a Grandfather's Day card, because grandfather may not be very accessible because mother's a lesbian. So just find a way around it. There are humorous ways around it.

Daughter: Remember in Grade 1-I didn't have a father so I made a card for Crumpet. Mother: Yes, like that. Then make a card for the cat.

Parents also discussed gender-specific parent/child events that require flexibility from schools. One mother shared,

I think the one thing that's a little bit sad for us is we don't really have anybody that I would send with [my son] to a Father's Day event... You know sometimes they have these father and son campouts at some schools, or father and daughter things. I guess we'll have to cross that bridge when it happens. We do have one or two family members I might feel comfortable approaching to take on that role if that's what [my children] would like. But I think that will be the only kind of tough part.

By creating alternative options for children with non-traditional family forms, teachers can prevent students from experiencing feelings of isolation during genderspecific holidays and events.

\section{Professionalism}

The participants were aware that teachers and administrators might hold personal and/or religious beliefs that are unsupportive of lesbian/gay individuals that may prevent them from actively supporting same-sex parented families in the classroom. Parents and adult children expressed the need for teachers to remain professional, 
even in situations that make them uncomfortable and/or with families with whom they might not agree. Some participants suggested that educators remain objective and focus solely on the children's educational needs. One adult child shared,

So I would say that schools should just support kids objectively and try and give them the best support that they can for that individual person.

Similarly, a mother responded,

I think take it on and say, 'You don't have to agree with it, you don't have to like it, but you have to accept it'... So I think it's, 'You believe what you want and I believe what I want, but this child needs to be properly educated'.

Another mother echoed the need for objectivity, and suggested that a teacher be removed if s/he is not able to do so. She explained,

For a teacher to exclude or discriminate against the child on the basis of their parents is unprofessional, totally. It should have nothing to do with the child, whatsoever, whether the parents are gay or not, because they're their own person...It's got nothing to do with the parents. So, in actual fact, if the teacher does that, they should be removed from the position, because the smallest thing in the child's life can create issues in adulthood, which comes out later. And that can mean that the smallest thing of saying something stupid, you know... They're there to protect the child... The teachers and lecturers are actually there to make the child's life easier.

Overall, participants believe that educators must remove their focus from the parents' identity, and instead focus on the needs of the children. For this to happen, however, some parents expressed the need for teachers to set aside religious teachings and influences within public schools. One father explained,

Almost every single Afrikaans school follows a Christian way of doing things. I think that's wrong... Children should not be taught by their teachers about Christ; it should be taught by the parents. And I think that is where the problem comes in in South Africa in terms of sexual diversity and those kinds of things...Although Christian principles (hard work, respect) seem to be a good vehicle to promote good education in a school context, I do think that these principles can be taught without using Christianity as a vehicle. The incorporation of Christianity in the public school context is thus not necessary and there is no legal, social or academic justification for it.

Parents feel that, though it may be difficult, teachers' religious beliefs should not prevent education about family diversity in the classroom, nor should they influence the ways in which children with lesbian/gay parents are treated in the classroom.

\section{Exposure to other lesbian/gay-parented families}

The final suggestion that parents and children provided to create a more supportive environment was for the schools to facilitate interactions with other lesbian/gay- 
parented families. Children specifically expressed the desire to meet other children with same-sex parents. One 15-year-old daughter shared,

I'd like to at least meet some teenagers. Cause I've never met any teenager who is in a household like that, so it would be nice to meet other children as well.

Similarly, an adult daughter shared,

I would suggest that they have a gay alliance club at school that supports kids like me growing up with a gay parent.

Parents also expressed the benefit for schools facilitating meetings between lesbian/ gay parents. One father explained,

In an ideal world, they could have same-sex parent evenings... and have a community around it so we could address issues that are common... You don't want to advertise as a gay school, but you could attract more same-sex parents. If you want to be that diverse of a school, you have to actually look for it.

This parent believes that having a gathering of lesbian/gay-parented families would not only benefit the families, but also attract more families to the school with a reputation for diversity.

\section{DISCUSSION}

Research shows that stigmatising experiences at school have a negative effect on the psychological health of children with lesbian/gay parents (Bos et al. 2008; Bos \& Van Balen 2008; Gartrell et al. 2005). Further, unsupportive school climates may indirectly affect children's academic success by discouraging active involvement from parents (Kosciw \& Diaz 2008; Lindsay et al. 2006). Despite the clear need for supportive school environments for lesbian/gay-parented families, very little is being done, both internationally and in South Africa, to foster these environments (Byard et al. 2013). In the current study, we explored the ways in which South African schools can begin to support these non-traditional family forms by examining the needs and suggestions of lesbian/gay parents and their children in these schools.

Parents and children in our study had a variety of experiences in the South African school system. Some families avoided negative experiences by remaining silent about their familial identity, similar to the children in Lubbe's (2007b) study of lesbian/gay-parented families in South African schools. Children who were more open about the parents' sexual orientation often reported experiencing at least one instance of teasing or bullying. Though most schools represented by the families have anti-bullying policies, only one of the schools (a Montessori school) has LGBT-specific policies. Participants suggested that anti-bullying policies that specifically include LGBT identities might be an important step toward the creation 
of affirming environments for LGBT individuals as well as lesbian/gay-parented families. Children with lesbian/gay-parented families report fewer negative school experiences when their schools' anti-bullying policies are LGBT-inclusive (Kosciw \& Diaz 2008). Simply having these policies, however, may not be effective unless they are actively acknowledged and enforced by administrators and educators (Russell, McGuire, Lee, Larriva \& Laub 2008). Russell et al. (2008) found that students report safer environments when schools take steps toward the creation of a better climate for lesbian/gay-parented families. The implementation of LGBT-specific policies is an important first step in creating these safe environments.

It is noteworthy that the children in our study reported minimal bullying and/or discrimination for having lesbian/gay parents. It is possible that the age of the children at the time of the interviews factored into their experiences of homonegativity, as children in high school tend to experience less bullying about their parents' sexual orientation than during preadolescence and early adolescence (Ray \& Gregory 2001). Another possible explanation for the lack of negativity from peers is that same-sex parented families often create supportive networks as preservation against negative discourse (Breshears \& Lubbe-De Beer, in press; Breshears \& Braithwaite 2014). It is imperative to mention that middle-class and upper middle-class parents may be able better to protect their children from bullying as they have greater geographic mobility and choice in schools (Goldberg 2010). Families with lower class status have fewer resources to guard themselves from homonegativity. Finally, it is possible that the lack of reported negativity was the result of a positivity bias in the interviews with the children. Children are sometimes cautious to acknowledge difficulty of having lesbian/gay parents out of concern that it may be attributed to their parents' sexual orientation. That is, they want to protect their families/parents and therefore only present the positive aspects of their family experience (Goldberg 2010). As many children chose to be interviewed with their parents present, they may have withheld negative experiences to protect their parents' feelings.

Participants in our study overwhelmingly expressed the need for more awareness and visibility of lesbian/gay-parented families in the classroom through education that focuses on the diversity of families in society. Families expressed the need for administrators and teachers to acknowledge non-traditional families in official forms and in classroom curricula. Further, participants expressed a need for children and their parents to become aware of lesbian/gay families and issues that sexual minorities face in society. The importance of visibility of lesbian/gayparented families in school is supported by extant research. Bos et al. (2008) found that children were less affected by stigma when their schools included lesbian/gay awareness in their curricula (see Byard et al. 2013 for inclusive curricular resources). Further, Kosciw, Greyak, Diaz, and Bartkiewicz (2010) found that LGBT students in schools with inclusive curricula were less likely to experience homophobia and victimisation at school. It is likely that children with lesbian/gay parents would 
experience less stigmatisation in these school environments as well. Participants also discussed the need for teacher sensitivity surrounding assignments, holidays, and events that may spotlight and/or isolate students with lesbian/gay parents. It is necessary for teachers to examine the ways in which their curricula and school activities can be more inclusive of non-traditional family forms.

Researchers in South Africa have begun to examine the needs of student teacher training, and have demonstrated the effectiveness of awareness-raising interventions in university courses with future educators (Johnson 2014; Richardson 2004; 2008). Organisations such as Gay and Lesbian Memory in Action (GALA) work with Life Orientation teachers in secondary schools to address the need for student teacher training regarding homophobia in schools (Johnson 2014). Despite these efforts, insufficient LGBT-inclusive training for staff members persists (Johnson 2014; Richardson 2004), which may be the simplest step for schools to implement toward supportive environments (Byard et al. 2013). As Richardson explains,

Although some teacher training institutions have attempted to address this need, and now offer short courses or workshops dealing with homophobia or heterosexism, they are not compelled to do so. Similarly, schools are not being compelled to ensure that their teachers uphold the rights of lesbian, gay, bisexual, and 'queer' (LGBQ) individuals. (2004, 146-147)

Further educator training is imperative for South African schools, as research has shown that much of the homophobia currently in the school system originates or is perpetuated by the teachers themselves (Bhana 2012; Francis 2012; Lubbe 2007b; Msibi 2012).

It is not surprising that the participants attributed this homonegativity to religious beliefs, considering the integral role of religious discourse in perpetuating homophobia (Breshears \& Braithwaite 2014; Bryant \& Demian 1994; Rostosky, Riggle, Brodnicki \& Olson 2008). In South Africa, specifically, researchers have noted the strong influence of religious ideology on attitudes toward sexual orientation (Punt 2006; Reddy 2006; Richardson 2004). As Butler et al. (2003, 6) explain, 'Reaction[s] against homosexual rights are seen, for many, as upholding religious beliefs and therefore something to be proud of and actively encouraged'. Families in the current study stressed the need for educators to set aside religious beliefs and maintain professionalism when working with parents and children in same-sex parented families. It is through training that teachers can face their own prejudices, discover the importance of supportive school climates on the well-being of children with lesbian/gay parents, and learn ways to create and implement inclusive curricula in their classroom.

Participants expressed the desire for more interaction between lesbian/gayparented families facilitated by the school through clubs or social gatherings. Student clubs or school-based initiatives, such as the Gay Straight Alliance found in many US high schools, may provide safe spaces for children to discuss their family identity, 
facilitate the meeting of other students with similar families, and communicate a supportive environment to lesbian/gay-parented families (Byard et al. 2013). Though these western programmes are not directly transferable to the South African context, they can serve as a prototype that educators can tailor to be culturally appropriate. At the very minimum, administrators and school counsellors should be aware of LGBT family community programmes to which they can refer families at their schools. This suggestion is consistent with Bos and van Balen's (2008) finding that children who interacted with other children with same-sex parents were less likely to experience the negative effects of stigmatisation on self-esteem.

\section{LIMITATIONS}

One limitation of this study pertains to the sample diversity. Although effort was made to recruit participants through a variety of methods and in diverse arenas, mostly white families responded. Diverse participant recruitment may have been further complicated by the fact that both researchers are white, English speakers, limiting our access to this often hidden demographic. Further research that is representative of all the various population groups in South Africa is definitely warranted. Another limitation to our study is the small number of adult children who participated. Adult children are invaluable because they are able to discuss their experiences across time and their maturity allows them to interpret their experiences (Goldberg 2010). Furthermore, the younger children in the study had a difficult time articulating and interpreting their experiences, often because it was the first time they were asked to do so. Finally, that only two individual fathers and one male couple could be recruited is also a limitation. Research on gay fathers remains lacking in extant research despite the need for information on this unique family type. Lesbian/ gay family researchers need to improve recruitment techniques that increase the representation of gay fathers in our research.

This study highlights the potentially important role that schools play in creating safe and supportive learning environments for children with lesbian/gay parents. Awareness of the variety of family forms needs to be raised, and active classroom discussions need to take place within a fully inclusive atmosphere that signals a message of acceptance. Furthermore, school structures need to be accommodating, in terms of policies, staff conduct, and teacher professionalism. The sensitisation of teachers through training is key to bring about the necessary changes fully to include sexual minority families in the school system. The diversity of South Africa can certainly be seen as one of the country's assets and lesbian/gay-parented families contribute to this rich diversity. Though South African society may not be ready fully to embrace and celebrate this unique family form, it is imperative that children from these families feel safe and accepted in their places of learning. 


\section{REFERENCES}

Baptiste Jr, D.A. 1987. Psychotherapy with gay/lesbian couples and their children in 'stepfamilies': A challenge for marriage and family therapists. Journal of Homosexuality 14(1-2): 223-238.

Berkowitz, D. 2009. Theorizing lesbian and gay parenting: Past, present, and future scholarship. Journal of Family Theory \& Review 1(3): 117-132.

Bhana, D. 2012. Understanding and addressing homophobia in schools: A view from teachers. South African Journal of Education 32(3): 307-318.

Bos, H.M.W., N.K. Gartrell, H. Peyser and F. van Balen. 2008. The USA national longitudinal lesbian family study (NLLFS): Homophobia, psychological adjustment, and protective factors. Journal of Lesbian Studies 12(4): 455-471.

Bos, H.M.W. and F. van Balen. 2008. Children in planned lesbian families: Stigmatisation, psychological adjustment and protective factors. Culture, Health \& Sexuality 10(3): 221236.

Breshears, D. 2011. Understanding communication between lesbian parents and their children regarding outsider discourse about family identity. Journal of GLBT Family Studies 7(3): 264-284.

Breshears, D. and D.O. Braithwaite. 2014. Discursive struggles animating individuals' talk about their parents' coming out as lesbian or gay. Journal of Family Communication 14(3): 189207.

Breshears, D. and C. Lubbe-De Beer. (in press). Same-sex parented families' negotiation of minority social identity in South Africa. Journal of GLBT Family Studies.

Bryant, A.S. and Demian. 1994. Relationship characteristics of American gay and lesbian couples: Findings from a national survey. Journal of Gay and Lesbian Social Service 1(2): 101-117.

Butler, A.H., A.H. Alpaslan, J. Strümpher and G. Astbury. 2003. Gay and lesbian youth experiences of homophobia in South African secondary education. Journal of Gay \& Lesbian Issues in Education 1(2): 3-28.

Byard, E., J. Kosciw and M. Bartkiewicz. 2013. Schools and LGBT-parent families: Creating change through programming and advocacy. In LGBT-parent families: Innovations in research and implications for practice. Edited by A.E. Goldberg and K.R. Allen. New York: Springer.

Casper, V., S. Schultz and E. Wickens. 1992. Breaking the silences: Lesbian and gay parents and the schools. Teachers College Record 94(1): 109-137.

Corbin, J. and A. Strauss. 2008. Basics of qualitative research: Techniques and procedures for developing grounded theory. 3rd edition. Los Angeles, CA: Sage.

Crouch, S., E. Waters, R. Mcnair, J. Power, E. Davis and L. Van Mourik. 2014. Triumphs and challenges in recruiting same-sex parent families. Australian and New Zealand journal of public health 38(1): 87-88.

Fedewa, A.L. and T.P. Clark. 2009. Parent practices and home-school partnerships: A differential effect for children with same-sex coupled parents? Journal of GLBT Family Studies 5(4): 312-339.

Francis, D. and T. Msibi. 2011. Teaching about heterosexism: Challenging homophobia in South Africa. Journal of LGBT Youth 8(2): 157-173. 
Francis, D.A. 2012. Teacher positioning on the teaching of sexual diversity in South African schools. Culture, Health \& Sexuality: An International Journal for Research, Intervention and Care 14(6): 597-611.

Gartrell, N., A. Deck, C. Rodas, H. Peyser and A. Banks. 2005. The national lesbian family study: 4. Interviews with the 10-year-old children. American Journal of Orthopsychiatry 75(4): $518-524$.

Goldberg, A.E. 2010. Lesbian and gay parents and their children: Research on the family life cycle. Washington, DC: American Psychological Association.

Johnson, B. 2014. The need to prepare future teachers to understand and combat homophobia in schools. South African Journal of Higher Education 28(4): 1249-1268.

Knoesen, E. 2004. Queering the vote. Mail \& Guardian, 03 March.

Kosciw, J.G. and E.M. Diaz. 2008. Involved, invisible, ignored: The experiences of lesbian, gay, bisexual, and transgender parents and their children in our nation's K-12 schools. New York: Gay, Lesbian and Straight Education Network.

Kosciw, J.G., E.A. Greytak, E.M. Diaz and M.J. Bartkiewicz. 2010. The 2009 National School Climate Survey: The experiences of lesbian, gay, bisexual and transgender youth in our nation's schools. New York: Gay, Lesbian and Straight Education Network.

Lewis, K.G. 1980. Children of lesbians: Their point of view. Social Work 25(3): 198-203.

Lindsay, J., A. Perlesz, R. Brown, R. Mcnair, D. De Vaus and M. Pitts. 2006. Stigma or respect: Lesbian-parented families negotiating school settings. Sociology 40(6): 1059-1077.

Lubbe, C. 2007a. Mothers, fathers, or parents: Same-gendered families in South Africa. South African Journal of Psychology 37(2): 260-283.

Lubbe, C. 2007b. To tell or not to tell: How children of same-gender parents negotiate their lives at school. Education as Change 11(2): 45-65.

Msibi, T. 2012. 'I'm used to it now': Experiences of homophobia among queer youth in South African township schools. Gender and Education 24(5): 515-533.

Pew Research Center. 2013. The global divide on homosexuality: Greater acceptance in more secular and affluent countries. Retrieved from: http://www.pewglobal.org/2013/06/04/theglobal-divide-on-homosexuality/ (accessed 13 December 2015).

Punt, J. 2006. Using the Bible in post-apartheid South Africa: Its influence and impact amidst the gay debate. HTS Teologiese Studies/Theological Studies 62: 885-907.

Ray, V. and R. Gregory. 2001. School experiences of the children of lesbian and gay parents. Family Matters 59: 28-34.

Reddy, V. 2006. Decriminalisation of homosexuality in post-apartheid South Africa: A brief legal case history review from sodomy to marriage. Agenda: Empowering Women for Gender Equity 20(67): 146-157.

Richardson, E.M. 2004. 'A ripple in the pond': Challenging homophobia in a teacher education course. Education as Change 8(1): 146-163.

Richardson, E.M. 2008. Using a film to challenge heteronormativity: South African teachers 'get real' in working with LGB youth. Journal of LGBT Youth 5(2): 63-72.

Roberts, B. and Reddy, V. 2008. Pride and prejudice: Public attitudes toward homosexuality. HSRC Review 6(4):9-11. Retrieved from: http://www.hsrc.ac.za/uploads/pageContent/1607/ Pride\%20and\%20Prejudice.pdf (accessed 9 December 2015). 
Rostosky, S.S., E.D.B. Riggle, C. Brodnicki and A. Olson. 2008. An exploration of lived religion in same-sex couples from Judeo-Christian traditions. Family Process 47(3): 389-403.

Russell, S.T., J.K. McGuire, S. Lee, J.C. Larriva and C. Laub. 2008. Adolescent perceptions of school safety for students with lesbian, gay, bisexual, and transgender parents. Journal of LGBT Youth 5(4): 11-27.

Singh, D. 1995. Discrimination against lesbians in family law. South African Journal on Human Rights 11: 571-581.

Smith, J.A. 1995. Semi-structured interviewing and qualitative analysis. In Rethinking methods in psychology. Edited by J.A. Smith, R. Harré and L.V. Langenhove. Thousand Oaks, CA: Sage.

Strauss, A. and J. Corbin. 1998. Basics of qualitative research: Techniques and procedures for developing grounded theory. Thousand Oaks, CA: Sage. 